\title{
PENGEMBANGAN MEDIA GAYANGHETUM (GAMBAR WAYANG HEWAN DAN TUMBUHAN) DALAM PEMBELAJARAN TEMATIK TERINTEGRASI KELAS IV SD
}

\author{
1) Rizki Oktavianti ${ }^{1}$, 2) Agus Wiyanto \\ 1Program Studi PGSD IKIP PGRI Semarang \\ Jl. Sidodadi Timur No. 24 Semarang \\ Email: AgusWiyanto7@gmail.com
}

\begin{abstract}
Lack of concentration learned in grade IV Elementary School N 01 Tegorejo due to the learning process is still given over monotonous so easily bored students in learning activities, and the lack of use of the environment as a medium of learning were encountered in the learning process. An environment where learning can simultaneously be used as a study material which has many benefits. Management and efficient utilization of the environment can produce a product that teaching has a high educational level. Based on these problems GAYANGHETUM media can be used as an alternative to learning. This type of research is the Research and Development is the development of instructional media. Media GAYANGHETUM is the development of an effective puppet media for use in learning. Analysis of test media expert GAYANGHETUM feasibility level by $90 \%$, feasibility of matter $88.33 \%$, and $91.48 \%$ was obtained from a questionnaire students who agree GAYANGHETUM media used in the study. Keywords: media gayanghetum, integrated thematic learning, class IV semester 1 elementary school.
\end{abstract}

\begin{abstract}
ABSTRAK
Kurangnya konsentrasi belajar pada siswa kelas IV SD N 01 Tegorejo disebabkan proses pembelajaran yang diberikan selama ini masih bersifat monoton sehingga siswa mudah merasa jenuh dalam melakukan kegiatan pembelajaran, serta kurangnya pemanfaatan lingkungan sebagai media pembelajaran merupakan hal yang dijumpai dalam proses pembelajaran. Lingkungan merupakan tempat belajar sekaligus dapat dijadikan suatu bahan belajar yang memiliki banyak manfaat. Pengelolaan dan pemanfaatan lingkungan dengan efisien dapat menghasilkan suatu produk pengajaran yang memiliki tingkat edukasi yang tinggi. Berdasarkan permasalahan tersebut media GAYANGHETUM dapat dijadikan sebagai alternatif dalam pembelajaran. Jenis penelitan ini adalah Research and Development berupa pengembangan media pembelajaran. Media GAYANGHETUM merupakan pengembangan dari media wayang yang efektif untuk digunakan dalam pembelajaran. Analisis uji ahli tingkat kelayakan media GAYANGHETUM sebesar 90\%, kelayakan materi 88,33\%, serta 91,48\% diperoleh dari angket siswa yang menyatakan setuju media GAYANGHETUM digunakan dalam pembelajaran.
\end{abstract}

Kata kunci: media gayanghetum, pembelajaran tematik terintegrasi, kelas IV semester 1 SD.

PENDAHULUAN Pada hakikatnya belajar adalah suatu kegiatan berfikir dan berbuat, oleh karena itu siswa harus turut terlibat dalam proses pembelajaran sehingga terjadi interaksi yang melibatkan beberapa komponen yang salah satunya adalah interaksi dengan lingkungan (Hamalik, 2008: 139). Lingkungan merupakan suatu bahan belajar yang memiliki banyak manfaat. Pengelolaan dan pemanfaatan lingkungan dengan efisien dapat menghasilkan suatu produk pengajaran yang memiliki tingkat edukasi yang tinggi. Namun, fenomena kurang memanfaatkan fasilitas dan lingkungan sering terjadi di sekolah, para guru pada umumnya melakukan proses belajar dikelas dengan pemberian materi-materi secara abstrak yang tidak diperbanyak dengan interaksi. Jika diamati, banyak sekali lingkungan sekitar sekolah yang dapat dimanfaatkan misalnya pohon, tiang bendera, bahan-bahan bekas, dan sebagainya. 
Objek-objek tersebut dapat dimanfaatkan oleh guru sebagai kegiatan untuk memecahkan suatu masalah dan untuk tercapainya kemampuan berkomunikasi sehingga dengan demikian kompetensi yang akan dicapai oleh peserta didik dapat tercapai.

Faktor yang juga berpengaruh terhadap keberhasilan pembelajaran adalah media pembelajaran yang di gunakan oleh guru dalam proses pembelajarannya, karena media pembelajaran merupakan perantara atau pengantar terjadinya komunikasi yang baik dan menyenangkan antara guru dengan siswanya. Semangat belajar siswa akan muncul ketika suasana begitu menyenangkan dan belajar akan efektif bila seseorang dalam keadaan gembira dalam belajar. Kemampuan guru dalam merancang dan menerapkan media pembelajaranlah yang merupakan kunci dari keberhasilan proses pembelajaran yang menyenangkan.

Menurut hasil wawancara dengan guru kelas IV SD N 01 Tegorejo yaitu Sudjiati S.Pd, konsentrasi siswa pada pembelajaran hanya sepuluh hingga lima belas menit pada awal materi pembelajaran. Khususnya, pada materi kelas IV Kurikulum 2013 tema III yaitu Peduli Terhadap Makhluk Hidup sub tema I Hewan dan Tumbuhan di Lingkungan Rumahku, mata pelajaran IPS, IPA, Matematika, SBdP, dengan rincian sebagai berikut: pada sub tema ini seluruh mata pelajaran menggunakan KI 3 . Memahami pengetahuan faktual dengan cara mengamati dan mencoba (mendengar, melihat, membaca) serta menanya berdasarkan rasa ingin tahusecara kritis tentang dirinya, makhluk ciptaan Tuhan dan kegiatannya, dan bendabenda yang dijumpainya dirumah, sekolah, dan tempat bermain, dengan dilengkapi, IPS KD 3.5. Memahami manusia dalam dinamika interaksi dengan lingkungan alam, sosial, budaya dan ekonomi, IPA KD 3.1 Menjelaskan bentuk luar tubuh hewan dan tumbuhan dan fungsinya, Matematika KD 3.1 Mengenal konsep pecahan senilai dan melakukan operasi hitung pecahan menggunakan benda kongkret/gambar, SBdP (Seni Budaya dan Prakarya) KD 3.2 Mengenal gambar alam, benda, dan kolase. Konsentrasi belajar siswa yang hanya sepuluh hingga lima belas menit itulah yang menyebabkan hasil belajar siswa rendah (Kemendikbud, 2013).
Sesuai dengan teori Peaget dan subtema pada pembelajaran satu yang membahas tentang lingkungan yang ada di sekitar, seorang guru yang berperan sebagai tenaga pendidik harus mampu membuat suatu media kongkrit yang dikemas secara menarik untuk menstimulasi siswa agar tertarik dan bersemangat dalam mengikuti dan memahami materi yang disampaikan guru.

Media yang akan digunakan untuk pembelajaran tidak harus berupa media yang memiliki nilai nominal yang tinggi. Berdasarkan tema yang penulis pilih, pemanfaatan lingkungan yang ada dapat dimanfaatkan sebagai media pembelajaran yang efektif, salah satunya dengan menciptakan media wayang dengan menggunakan bahan/barang bekas yang ada dilingkungan sekitar.

Media wayang merupakan media yang menarik untuk digunakan dalam proses pembelajaran. Selain untuk mengajarkan tentang kebudayaan Indonesia media wayang dapat dikembangkan menjadi media pembelajaran yang disesuaikan dengan materi pembelajaran yang akan dipelajari. Pada dasarnya masyarakat mengenal wayang hanya dalam cerita atau legenda dari Jawa. Namun dengan perkembangan zaman wayang dapat digunakan sebagai media yang edukatif dan efektif dalam pembelajaran dengan kemasan yang berbeda dan menarik minat belajar siswa. Media wayang dapat diciptakan dengan bahan-bahan yang mudah. Anafi seorang mahasiswa Universitas Negeri Yogyakarta menggunakan media wayang boneka sebagai media bantu dalam pembelajaran Bahasa Indonesia (Anafi, 2012). Selain itu, (Haritz, 2011) menyatakan bahwa "sebenarnya media pewayangan tidak harus terikat dalam satu sifat materi pelajaran itu sendiri. Artinya, seorang guru tidak mengajar hanya disesuaikan dengan materi pembelajaran satu saja, akan tetapi juga implikatif digunakan untuk materi pelajaran yang lain."

Berdasarkan materi yang diteliti oleh peneliti, yaitu dengan materi Hewan dan Tumbuhan di Lingkungan Rumahku, peneliti mengemas media wayang dengan media baru yaitu dengan nama GAYANGHETUM (Gambar Wayang dan Hewan Tumbuhan). Media GAYANGHETUM ini mencakup segala aspek yang terdapat dalam pembelajaran, tidak hanya terfokus pada 
pembelajaran IPA saja, namun di dalam media ini terdapat suatu kegiatan bercerita, menghitung, membutuhkan aktifitas fisik siswa, dan interaksi antar siswa.

Untuk membatasi kajian, maka peneliti merumuskannya ke dalam dua pertanyaan berikut:

1. Bagaimanakah pengembangan Media GAYANGHETUM (Gambar Wayang Hewan dan Tumbuhan) pada pembelajaran tematik terintegrasi kelas IV semester I?

2. Apakah Media GAYANGHETUM (Gambar Wayang Hewan dan Tumbuhan) efektif digunakan pada pembelajaran tematik terintegrasi kelas IV semester I?

\section{Pengembangan}

Pengembangan didefinisikan sebagai aplikasi sistematis dari pengetahuan atau pemahaman, diarahkan pada produksi bahan yang bermanfaat, perangkat, dan sistem atau metode, termasuk desain, pengembangan dan peningkatan prioritas, serta proses baru untuk memenuhi persyaratan tertentu (Putra, 2012: 70).

"Metode penelitian dan pengembangan atau dalam bahasa Inggrisnya Reasearch and Development adalah metode penelitian yang digunakan untuk menghasilkan produk tertentu dan menguji keefektifan produk tersebut". (Sugiyono, 2010: 407).

"Pengembangan pembelajaran adalah suatu proses mendesain pembelajaran secara logis dan sistematis dalam rangka untuk menetapkan segala sesuatu yang akan dilaksanakan dalam proses kegiatan belajar dengan memperhatikan potensi dan kompetensi siswa." (Rahmawati, 2006)

Pengembangan dalam pembelajaran diperlukan agar proses dalam pembelajaran terdapat suatu variasi yang baru dengan menghasilkan suatu produk yang dapat menunjang dalam kegiatan pembelajaran tersebut.

\section{Media Pembelajaran}

Media pembelajaran dengan alat peraga pembelajaran memiliki banyak persamaan, keduanya berfungsi memudahkan siswa untuk memahami materi belajar. Namun para ahli memberikan beberapa pendapat tentang perbedaan antara alat peraga pembelajaran dan media pembelajaran. Menurut Ruiz, (2009) dalam (Asyhar, 2012:13) bahwa "Papan tulis yang digunakan guru untuk menyampaikan informasi kepada peserta didik, disebut alat peraga, sedangkan apa yang disampaikan pada papan tulis berupa gambar, teks, dan sejenisnya adalah media. Sedangkan menurut Sanaky (Asyhar, 2012:13) menyatakan bahwa "Papan tulis yang sejatinya merupakan alat pembelajaran, baru bisa dikatakan sebagai suatu mdia pembelajaran jika sudah secara definitif digunakan untukmenyampaikan pesan dan informasi.

Media pembelajaran memiliki manfaat dan fungsi penting dalam proses kegiatan pembelajaran. Menurut Hamalik dikutip (Arsyad, 2011:19) mengemukakan bahwa "pemakaian media pembelajaran dalam proses belajar mengajar dapat membangkitkan keinginan dan minat yang baru, membangkitkan motivasi dan rangsangan kegiatan belajar, dan membawa pengaruh-pengaruh psikologis terhadap siswa". Penggunaan media pembelajaran pada tahap orientasi pembelajaran akan sangat membantu keefektifan proses pembelajaran dan penyampaian pesan dan isi pelajaran saat itu. Sedangkan manfaat media dalam proses belajar mengajar antara lain:

1. Dapat memperjelas penyajian pesan dan informasi sehingga dapat memperlancar dan meningkatkan proses dan hasil belajar

2. Dapat meningkatkan dan mengarahkan perhatian anak sehingga dapat menimbulkan motivasi belajar.

Menurut Sudjana dan Rivai dikutip (Arsyad, 2011:28) mengemukakan manfaat media pembelajaran dalam proses belajar siswa yaitu;

1. Pembelajaran akan lebih menarik perhatian siswa sehingga dapat menumbuhkan motivasi belajar

2. Bahan pembelajaran akan lebih jelas maknanya sehnga dapat lebih dipahami oleh siswa dan memungkinkannya menguasai dan mencapai tujuan pembelajaran

3. Metode belajar akan lebih bervariasi, tidak semata-mata komunikasi verbal melalui penuturan kata-kata ole guru, sehingga siswa tidak bosan dan guru tidak kehabisan tenaga, apalagi kalau guru mengajar pada setiap jam mata pelajaran

4. Siswa dapat lebih banyak melakukan kegiatan belajar sebab tidak hanya 
mendengarkan uraian guru, tetapi juga aktivitas lain sepeti mengamati, melakukan, mendemonstrasikan, memerankan, dan lainlain.

Berdasarkan ungkapan dari para ahli tersebut, dapat disimpulkan bahwa media pembelajaran memiliki fungsi dan manfaat bagi siswa dan guru untuk terciptanya proses kegiatan belajar mengajar yang optimal.

\section{Wayang dan Media Wayang}

Wayang sering dipandang sebagai suatu hal yang kuno, yang tidak mudah dipahami oleh banyak orang. Khususnya siswa-siswa sekolah dasar yang pada masa-masa ini sudah jarang menjumpai suatu kontes atau pertunjukan wayang tradisional, mereka lebih mengenal cerita-cerita yang dikemas secara modern. Namun dengan seiring perkembangan jaman wayang sering ditampilkan dengan berbagai bahasa dan tidak hanya berpatokan dengan cerita atau legenda dari jawa.

Wayang merupakan inovasi baru untuk pendidikan, yaitu digunakan sebagai media pembelajaran yang menyenangkan. Para guru mulai kreatif dalam menciptakan suatu mediamedia baru untuk menunjang keberhasilan dalam pembelajaran dan mendapat suatu tanggapan yang baik dari siswa. Wayang dapat dijadikan suatu alternatif bagi guru sebagai suatu media untuk meningkatkan minat dan hasil belajar siswa terhadap pembelajaran yang akan dilaksanakan.

\section{GAYANGHETUM (Gambar Wayang Hewan dan Tumbuhan)}

Media GAYANGHETUM merupakan pengembangan media yang dikemas sebagai media pembelajaran berbentuk media gambar dengan menggabungkan antara permainan warna dengan teknik kolase yang digunakan pada siswa SD kelas IV berbasis tematik terintegrasi. Media GAYANGHETUM berbentuk hewan dan tumbuhan. Biasanya jika mendengar kata wayang yang terlintas dalam pikiran itu adalah sebuah tokoh pewayangan yang berasal dari suatu cerita atau legenda daerah. Namun dengan GAYANGHETUM masyarakat khususnya para siswa dikenalkan sebuah hal baru yaitu tentang wayang yang digunakan sebagai media pembelajaran yang lakonnya adalah hewan dan tumbuhan dengan alur cerita yang berbeda yang dikemas sesuai dengan kebutuhan materi pembelajaran yang akan diajarkan.

\section{METODE}

Jenis penelitian yang digunakan peneliti adalah penelitian dan pengembangan (Research and Development) dengan subjek siswa SD kelas IV SD N 01 tegorejo yang dilaksanakan pada bulan Januari 2014. Jenis penelitian dan pengembangan dipilih oleh peneliti, karena peneliti mengembangkan produk berupa media pembelajaran. Media pembelajaran yang digunakan peneliti ini merupakan media pengembangan dari media wayang yang sudah ada. Prosedur pengembangan Media GAYANGHETUM menggunakan Media ADDIE (Analysis, Design, Development, Implementation, Evaluation).

Penelitian dan pengembangan ini menggunakan dua teknik analisis data yaitu teknik analisis deskriptif kualitatif dan analisis deskriptif kuantitatif. Dalam penelitian ini, data kualitafif berupa komentar dan saran perbaikan produk dari ahli media pembelajaran dan ahli materi pembelajaran bidang studi yang nantinya akan dideskriptifkan secara deskriptif kualitatif untuk merevisi produk yang dikembangkan. Sedangkan data kuantitatif, yaitu data berupa skor penilaian ahli media pembelajaran, ahli materi pembelajaran bidang studi yang berupa pengisian lembar angket.

Pengumpulan data dengan angket, yakni dengan cara pengumpulan data dengan menggunakan daftar pertanyaan yang telah disiapkan agar responden mampu mengisi jawaban dengan cepat dan mudah. Data yang digunakan untuk menguji validitas materi dan media menggunakan data angket dengan validator memberikan tanda centang pada kolom pilihan, selain itu validator juga menulis komentar-komentar tentang kekurangan pada materi ataupun media yang diujikan. Hal ini bertujuan agar materi atau media dapat disempurnakan. Angket juga digunakan untuk mengukur ketertarikan siswa pada media GAYANGHETUM, karena menggunakan angket, siswa diminta untuk memberikan tanda silang pada pilihan jawaban angket yang telah disediakan. 
Analisis data yang digunakan untuk mengolah data perolehan dari angket validasi produk pengembangan bersifat deskriptif kuantitatif dan deskripif kualitatif. Data kualitatif berupa komentar dan saran mengenai Media GAYANGHETUM akan diinterpretasikan peneliti dalam bentuk penjelasan atau narasi, sedangkan data kuantitatif dari tiap-tiap item instrumen dihitung dengan menggunakan distribusi frekuensi kemudian dijelaskan dalam bentuk kalimat. Menurut (Riduwan, 2010:66) “kegunaan data yang masuk dalam distribusi frekuensi adalah untuk memudahkan data dalam penyajian, mudah dipahami dan mudah dibaca sebagai bahan informasi".

Distribusi frekuensi yang digunakan peneliti adalah distribusi frekuensi kategori. (Riduwan, 2010:66) mengatakan "distribusi frekuensi kategori ialah distribusi frekuensi yang pengelompokan datanya disusun berbentuk kata-kata atau distribusi frekuensi yang penyatuan kelas-kelasnya didasarkan pada data kategori (kualitatif)".

Distribusi frekuensi digunakan untuk menyajikan jumlah jawaban siswa pada angket tanggapan Media GAYANGHETUM.

\section{HASIL DAN PEMBAHASAN}

Berdasarkan hasil analisis kebutuhan di lapangan, peneliti mengembangkan media GAYANGHETUM yang mengarahkan gaya belajar positif bagi siswa, yaitu lebih fokus terhadap materi pembelajaran, mencintai lingkungan sekitar dan dapat memanfaatkan benda-benda tak terpakai yang ada di lingkungan sekitar. Media GAYANGHETUM yang dikembangkan ini diterapkan di dalam pembelajaran untuk kelas IV SD, sehingga peneliti menyusun perangkat pembelajaran berupa Rencana Pelaksanaan Pembelajaran (RPP), penilaian, dan bahan ajar. Perangkat pembelajaran tentang media GAYANGHETUM yang disusun peneliti merupakan bahan yang digunakan untuk validasi kepada validator atau ahli, sehingga diperoleh data mengenai kelayakan media GAYANGHETUM jika diterapkan dalam pembelajaran sekaligus komentar dan saran untuk merevisi media.

\section{Hasil Pengembangan Media GAYANGHETUM}

Media GAYANGHETUM ini dikembangkan berdasarkan langkah-langkah penelitian dan pengembangan (research and development). Metode penelitian dan pengembangan adalah metode yang digunakan untuk menghasilkan produk tertentu, dan menguji keefektifan produk tersebut. Prosedur pengembangan menggunakan ADDIE yaitu analisis, desain, pengembangan, implementasi, evaluation.

Desain yang digunakan dalam Media GAYANGHETUM dikembangkan dari wayang tradisonal jawa yang digunakan sebagai media pembelajaran serta penggunaan wayang boneka sebagai media bantu pembelajaran. Wayang digunakan sebagai media pembelajaran dengan berfokus pada satu mata pelajaran. Pada pengembangan penelitian ini media wayang dikembangkan menjadi media GAYANGHETUM yang merupakan kependekan dari gambar wayang hewan dan tumbuhan. Media GAYANGHETUM merupakan media yang menggunakan gambar hewan dan tumbuhan yang dibentuk menggunakan teknik kolase dan perpaduan warna yang menarik sesuai dengan karakter siswa SD. Media GAYANGHETUM dibuat dengan bahan yang mudah dijumpai di lingkungan masyarakat, bahan-bahan yang digunakan yaitu pelepah pisang yang dikeringkan menjadi bahan dasar media GAYANGHETUM. Pelepah pisang dimanfaatkan sebagai alas media GAYANGHETUM yang dipadukan dengan teknik kolase yang berbahan dasar kapas dan dibentuk sesuai bentuk hewan dan tumbuhan pada materi pembelajaran serta sentuhan warna yang menarik dari pewarna makanan. Media GAYANGHETUM merupakan media pengembangan dari media wayang yang cara penerapannya menggunakan konsep mendalang.

Desain media yang telah dikembangkan kemudian divalidasi oleh pakar atau validator sebelum diujicobakan. Validator terdiri dari ahli Media GAYANGHETUM dan ahli materi Tematik (IPA, IPS, SBdP dan Matematika). Berdasarkan hasil revisi oleh pakar atau validator ahli media dilakukan perbaikan pada sintaks Media GAYANGHETUM, selain itu peneliti juga membuat buku panduan penggunaan Media GAYANGHETUM dan contoh penerapan dalam pembelajaran dalam 
RPP, sedangkan berdasarkan hasil revisi oleh pakar atau validator ahli materi dilakukan perbaikan pada struktur kalimat pada penilaian evaluasi materi. Sehingga dengan adanya perbaikan diharapkan Media GAYANGHETUM dapat efektif digunakan dalam pembelajaran.

\section{Pengembangan Media GAYANGHETUM Efektif digunakan dalam Pembelajaran}

Media GAYANGHETUM, efektif digunakan dalam proses pembelajaran. Keefektifan media GAYANGHETUM ini dinilai dari lima aspek yaitu a) aspek media dari validator dengan presentase keefektifan sebesar $90 \%$ b) aspek materi dari validator dengan presentase keefektifan sebesar $88,33 \%$ c) aspek media dari penilaian guru dengan presentase keefektifan sebesar $90 \%$ d) aspek materi dari penilaian guru dengan presentase keefektifan sebesar 90\% e) aspek minat siswa terhadap media GAYANGHETUM dengan presentase keefektifan sebesar 91,48\%. Dari total presentase kelima aspek media GAYANGHETUM efektif untuk digunakan dalam pembelajaran dengan hasil presentase $89,96 \%$.

\section{SIMPULAN}

Berdasarkan rumusan masalah dan hasil penelitian yang dilaksanakan melalui penelitian dan pengembangan dapat disimpulkan bahwa:

Pengembangan media GAYANGHETUM disesuaikan dengan Kompetensi Inti dan Kompetensi dasar yang digunakan untuk pembelajaran. Media GAYANGHETUM dilakukan berdasarkan langkah-langkah pengembangan yaitu melihat adanya potensi masalah, mengumpulkan data, mendesain produk, validasi desain, revisi desain, uji coba produk. Berdasarkan hasil presentase dari validator ahli media maupun materi dan tanggapan siswa menyatakan bahwa Media GAYANGHETUM layak digunakan dalam pembelajaran tematik terintegrasi siswa SD Kelas IV.

Media GAYANGHETUM efektif digunakan dalam proses pembelajaran. Hal ini berdasarkan hasil analisis uji validator dan guru, kelayakan presentase media GAYANGHETUM sebesar 90\%, kelayakan materi dari validator sebesar 88,33\%, sedangkan kelayakan materi diperoleh presentase sebesar $89,16 \%$, serta $91,48 \%$ diperoleh dari angket siswa yang menyatakan setuju media GAYANGHETUM digunakan dalam pembelajaran. Dari hasil analisis tersebut, media GAYANGHETUM dinyatakan sangat baik dan layak digunakan dalam pembelajaran sesuai dengan range bobot presentase yang ditentukan oleh Arikunto sebesar 81\%-100\%.

\section{REFERENSI}

Anafi. (2012). "Peninggkatan Keterampilan Bercerita dengan Menggunakan Wayang Boneka pada Siswa Kelas VII B SMP N 1 Sayegan Sleman". Diakses 18 Februari 2014 dari: Eprints.uny.ac.id.

Asyhar, Rayandra. (2012). Kreatif Mengembangkan Media Pembelajaran. Jakarta: GP Press.

Arsyad, Azhar. (2011). Media Pembelajaran. Jakarta: PT Raja Grafindo Persada.

Haritz, Eka (2011). "Wayang Sebagai Media Pembelajaran". Diakses pada 12 November 2013 dari: http//haritzeka.blogspot.com.2013/03/wayangsebagai-mediapembelajaran. html.

Hamalik, Oemar. (2008). Pendekatan Baru Strategi Belajar Mengajar Berdasarkan CBSA. Bandung: Sinar Baru Algensindo.

Kemendikbud. (2013). Kurikulum 2013 Kompetensi Dasar. Jakarta: Kemendikbud.

Putra, Nusa. (2012). Research \& Development. Jakarta: PT Raja Grafindo Persada.

Rahmawati, Evi. (2006). "Pengertian Pengembangan". Diakses 19 februari 2014 darri: Library.walisongo.ac.id.

Riduwan. (2010). Dasar-dasar Statistika Edisi Revisi. Bandung: Alfabeta.

Sugiyono. 2010. Matode Penelitian Pendidikan (Pendekatan Kuantitatif, Kualitatif, dan R\&D). Bandung: Alfabeta. 